\title{
Early neurobiological changes in childhood after traumatization
}

\author{
Apostolos Vourdas
}

From $1^{\text {st }}$ International Congress on Neurobiology and Clinical Psychopharmacology and European

Psychiatric Association Conference on Treatment Guidance

Thessaloniki, Greece. 19-22 November 2009

It is widely accepted that traumatic experiences during critical stages of child development can predispose in clinical conditions such as anxiety, depression, post traumatic stress disorder symptoms, personality disorder etc. The research about the developmental implications of trauma on the biological systems responsible for the modulation of stress is on its early stages. The involvement of endocrinological and neurochemical changes has long been described. Recently, neuroimmaging as well as molecular genetics findings have been reported. The exploration and understanding of the above biological mechanisms may lead to preventive strategies or more effective treatment for children who have fallen victims of abuse, neglect or trauma.

Published: 22 April 2010

\section{doi:10.1186/1744-859X-9-S1-S28}

Cite this article as: Vourdas: Early neurobiological changes in childhood after traumatization. Annals of General Psychiatry 2010 9(Suppl 1):S28.
Hallowell Center, Athens, Greece

@ 2009 Vourdas; licensee BioMed Central Ltd.
Submit your next manuscript to BioMed Central and take full advantage of:

- Convenient online submission

- Thorough peer review

- No space constraints or color figure charges

- Immediate publication on acceptance

- Inclusion in PubMed, CAS, Scopus and Google Scholar

- Research which is freely available for redistribution

Submit your manuscript at www.biomedcentral.com/submit 